\title{
Cuticular hydrocarbons for the identification and geographic assignment of empty puparia of forensically important flies
}

\author{
Hannah Moore ${ }^{1}$ (D) $\cdot$ Lena Lutz ${ }^{2} \cdot$ Victoria Bernhardt $^{2} \cdot$ Falko P. Drijhout $^{3} \cdot$ Robert B. Cody $^{4} \cdot$ Jens Amendt $^{2}$
}

Received: 28 September 2021 / Accepted: 21 January 2022 / Published online: 26 February 2022

(c) The Author(s) 2022

\begin{abstract}
Research in social insects has shown that hydrocarbons on their cuticle are species-specific. This has also been proven for Diptera and is a promising tool for identifying important fly taxa in Forensic Entomology. Sometimes the empty puparia, in which the metamorphosis to the adult fly has taken place, can be the most useful entomological evidence at the crime scene. However, so far, they are used with little profit in criminal investigations due to the difficulties of reliably discriminate among different species. We analysed the $\mathrm{CHC}$ chemical profiles of empty puparia from seven forensically important blow flies Calliphora vicina, Chrysomya albiceps, Lucilia caesar, Lucilia sericata, Lucilia silvarum, Protophormia terraenovae, Phormia regina and the flesh fly Sarcophaga caerulescens. The aim was to use their profiles for identification but also investigate geographical differences by comparing profiles of the same species (here: C. vicina and L. sericata) from different regions. The cuticular hydrocarbons were extracted with hexane and analysed using gas chromatography-mass spectrometry. Our results reveal distinguishing differences within the cuticular hydrocarbon profiles allowing for identification of all analysed species. There were also differences shown in the profiles of $C$. vicina from Germany, Spain, Norway and England, indicating that geographical locations can be determined from this chemical analysis. Differences in L. sericata, sampled from England and two locations in Germany, were less pronounced, but there was even some indication that it may be possible to distinguish populations within Germany that are about $70 \mathrm{~km}$ apart from one another.
\end{abstract}

Keywords Cuticular hydrocarbons · GC-MS · PCA · Calliphoridae · Empty puparia · Forensic entomology

\section{Introduction}

Forensic entomology utilises insects that feed on dead tissue and decomposing remains to aid in legal investigations. Possible applications are investigations on mode and circumstances of death, post-mortem modifications of the body or the estimation of the time of death. The latter is performed by analysing the species composition of the necrophagous fauna or by estimating the age of the juvenile insects developing on the dead

Hannah Moore

h.e.moore@cranfield.ac.uk

1 Defence Academy of the United Kingdom, Cranfield Forensic Institute, Cranfield University, Shrivenham, Wiltshire SN6 8LA, UK

2 Institute of Legal Medicine, Forensic Biology, University Hospital, Goethe University, Frankfurt am Main, Germany

3 School of Physical and Geographical Sciences, Keele University, Staffordshire ST5 5BG, UK

4 JEOL USA, Inc. 11 Dearborn Rd, Peabody, MA 01969, USA body. Here, blow flies (Diptera: Calliphoridae) are most important as they often detect and colonise the dead body shortly after death, sometimes only a few hours post mortem. Their age leads to the minimum post mortem interval $\left(\mathrm{PMI}_{\min }\right)$, the period between the first insect colonisation and the discovery of the body. Many studies so far have focused on research on fly larvae and pupae and their age determination for the purpose of estimating the $\mathrm{PMI}_{\min }$ [1-5]. But after 3-4 weeks post mortem, the empty puparia, in which the metamorphosis of the larva via the pupal stage to the adult fly has taken place, are the oldest entomological evidence at the scene and sometimes even the only remnant and evidence of a development that has taken place [6]. Only little research is done on these empty puparia, and currently they are used with little profit in criminal investigations due to the difficulties of reliably discriminate among different species of closely related fly species, or assessing their age as there is no longer any visible change in morphology like the increase in length of the maggots.

However, in the last decade, studies have suggested that invaluable information can be obtained from puparia, and 
hence new methods for identification and further analyses are being developed [7].

DNA-based techniques show promising results to the field of forensic entomology when it comes to species identification [4, 8-11]. However, while many of these studies focus on juvenile or adult stages of Diptera (and other taxa) or their remains, just a few are dedicated to the identification of empty fly puparia [12]. While this method is promising for fresh material, DNA degradation during the process of ageing can deeply compromise the genetic analysis since the older the fly puparia, the smaller are the amplified DNA fragments [13]. An alternative technique to DNA which has proven its potential of accurately identifying and ageing forensically important species is cuticular hydrocarbon analysis.

Cuticular hydrocarbons (CHC) as a means of species identification has been studied for decades and is used to discriminate between different insect taxa $[14,15]$. Their epicuticular wax layer is consisting of hydrocarbons, fatty acids, alcohols, waxes, glycerides, phospholipids and glycolipids. This hydrophobic, flexible layer prevents desiccation as well as penetration of microorganisms [16]. Hydrocarbons predominate within this layer in many species of insects [13] and are found to be extremely stable [17]. Due to the vast number of different $\mathrm{CHC}$ and possible combinations, each species of insect holds its own unique hydrocarbon profile, often referred to as a chemical fingerprint [7, 18, 19].

$\mathrm{CHC}$ thus enable the identification of the various developmental stages of insects at the species level, but they can also be used to identify remains and fragments of such stages, like empty puparia, with the main advantage that species identification can not only be established on young, but also on old puparia (due to the stability of hydrocarbons) that have been crushed or deteriorated due to weathering, making the usual morphological characteristics difficult or impossible to visualise under a microscope [7].

The first aim of the present study was to establish the species-specific chemical profiles of the empty puparia from 7 forensically important blow flies and one flesh fly species. The second aim was to then focus on the puparia of two of the blow fly species, Calliphora vicina and Lucilia sericata, from three different geographical locations to determine whether possible local adaptations impact their chemical profiles and if so, whether this could affect species identification or even, conversely, allow differentiation of local variants.

\section{Materials and methods}

\section{Insect materials}

Empty puparia from 7 forensically important blow flies (Calliphora vicina, Chrysomya albiceps, Lucilia caesar, Lucilia sericata, Lucilia silvarum, Phormia regina and Protophormia terraenovae) and one flesh fly (Sarcophaga caerulescens) were analysed, thus covering the majority of the first colonisers of the families Calliphoridae and Sarcophagidae found on human cadavers in Europe according to Szpila [20] and Szpila et al. [21]. All species were sampled in Germany, while two blow fly species were additionally collected in England (C. vicina and L. sericata) and Norway and Spain (C. vicina). For L. sericata, different populations within Germany were also analysed (Table 1) from Frankfurt (Germany 1) and Steinau (Germany 2), which are approximately $70 \mathrm{~km}$ apart. Empty puparia of all species and populations were obtained by breeding the flies in the laboratory for less than 5 generations. The initial populations or parent generations were established by either baiting the flies in the field or by sampling insect larvae from human bodies during autopsy. Baited or sampled fly larvae were given mixed minced meat (pork and beef) and further reared in the laboratory. Resulting adult flies were held in rearing cages at room temperature (average temperature approximately $20^{\circ} \mathrm{C}$, $79 \% \mathrm{RH}$ ) and a 12:12 L:D cycle. They were provided with water and sugar ad libitum. A piece of fresh pork liver was regularly placed into the cage as a protein source and as oviposition (or, in the case of the flesh fly Sarcophaga caerulescens, as larviposition) medium. Resulting blow fly eggs and flesh fly larvae were transferred separately into an incubator, set between $20^{\circ} \mathrm{C} \pm 1{ }^{\circ} \mathrm{C}$. After $24 \mathrm{~h}$, larvae were transferred from the oviposition medium to mixed minced ad libitum in a plastic cup, which were placed in bigger plastic containers filled with $2 \mathrm{~cm}$ of sawdust, serving as the medium for pupariation. After pupariation, every container were checked once per day. After the first fly had hatched, another 3 days were waited, and all empty puparia present up to then were sampled and stored dry at room temperature and 12:12 L:D cycle.

\section{Sample preparation}

For each sample $(n=10)$, two puparia were used. They were placed into a $2 \mathrm{~mL}$ GC vial and submerged with hexane $(350 \mu \mathrm{L})$ for 10 to $15 \mathrm{~min}$. The hexane extract was collected in a clean $2-\mathrm{mL}$ vial and then left to evaporate until the extract could be transferred to a $300 \mu \mathrm{L}$ flat bottomed insert and left to dry down completely. All samples were stored dry in the refrigerator at $4{ }^{\circ} \mathrm{C}$ until they were required for analysis. The dried extract was then reconstituted in $30 \mu \mathrm{L}$ of hexane before GC-MS analysis which was carried out using the autosampler.

\section{Chemical analysis of extracts}

Chemical analysis of all extracts was carried out on an Agilent Technologies $6890 \mathrm{~N}$ Network GC with a split/ 
Table 1 List of species analysed, sorted according to systematics and origin; 10 specimens per species were analysed, with the exception of Lucilia sericata England $(n=8)$ and Protophormia terraenovae $(n=9)$

\begin{tabular}{|c|c|c|c|c|}
\hline \multicolumn{2}{|c|}{ Species/subpopulation } & Country & City/area & Latitude and longitude \\
\hline \multicolumn{5}{|c|}{ Sarcophagidae } \\
\hline 1 & Sarcophaga caerulescens Zetterstedt, 1838 & Germany & Hammelburg & $50^{\circ} 05^{\prime} \mathrm{N}, 9^{\circ} 86^{\prime} \mathrm{E}$ \\
\hline \multicolumn{5}{|c|}{ Calliphoridae } \\
\hline \multicolumn{5}{|c|}{ Calliphorinae } \\
\hline 2 & Calliphora vicina Robineau-Desvoidy, 1830 & England & Keele University & $53^{\circ} 013^{\prime} \mathrm{N}, 2^{\circ} 17^{\prime} \mathrm{W}$ \\
\hline 3 & Calliphora vicina & Germany & Frankfurt/Main & $50^{\circ} 11^{\prime} \mathrm{N}, 8^{\circ} 66^{\prime} \mathrm{E}$ \\
\hline 4 & Calliphora vicina & Norway & Ballstad & $68^{\circ} 05^{\prime} \mathrm{N}, 13^{\circ} 33^{\prime} \mathrm{E}$ \\
\hline 5 & Calliphora vicina & Spain & Villaviciosa de Odón & $40^{\circ} 21^{\prime} \mathrm{N}, 3^{\circ} 54^{\prime} \mathrm{W}$ \\
\hline \multicolumn{5}{|c|}{ Luciliinae } \\
\hline 6 & Lucilia caesar (Linnaeus, 1758) & Germany & Hannover & $52^{\circ} 39^{\prime} \mathrm{N}, 9.69^{\prime} \mathrm{E}$ \\
\hline 7 & Lucilia sericata (Meigen, 1826) & England & Keele University & $53^{\circ} 01^{\prime} \mathrm{N}, 2^{\circ} 17^{\prime} \mathrm{W}$ \\
\hline 8 & Lucilia sericata & Germany 1 & Frankfurt/Main & $50^{\circ} 11^{\prime} \mathrm{N}, 8^{\circ} 66^{\prime} \mathrm{E}$ \\
\hline 9 & Lucilia sericata & Germany 2 & Steinau & $50^{\circ} 31^{\prime} \mathrm{N}, 9^{\circ} 46^{\prime} \mathrm{E}$ \\
\hline 10 & Lucilia silvarum (Meigen, 1826) & Germany & Hammelburg & $50^{\circ} 05^{\prime} \mathrm{N}, 9^{\circ} 86^{\prime} \mathrm{E}$ \\
\hline \multicolumn{5}{|c|}{ Chrysomyiinae } \\
\hline 11 & Chrysomya albiceps (Wiedemann, 1819) & Germany & Frankfurt/Main & $50^{\circ} 11^{\prime} \mathrm{N}, 8^{\circ} 66^{\prime} \mathrm{E}$ \\
\hline 12 & Phormia regina (Meigen, 1826) & Germany & Frankfurt/Main & $50^{\circ} 11^{\prime} \mathrm{N}, 8^{\circ} 66^{\prime} \mathrm{E}$ \\
\hline 13 & Protophormia terraenovae (Robineau-Desvoidy, 1830) & Germany & Frankfurt/Main & $50^{\circ} 11^{\prime} \mathrm{N}, 8^{\circ} 66^{\prime} \mathrm{E}$ \\
\hline
\end{tabular}

splitless injector at $250{ }^{\circ} \mathrm{C}$, a Restek Rxi-1MS capillary column (30 m $\times 0.25 \mathrm{~mm}$ ID, $0.25 \mu \mathrm{m}$ film thickness) and coupled to an Agilent 5973 Network Mass Selective Detector. The GC was coupled to a computer and data processed with Agilent Chemstation software. Elution was carried out with helium at $1 \mathrm{~mL} / \mathrm{min}$. The oven temperature was programmed to be held at $50{ }^{\circ} \mathrm{C}$ for $2 \mathrm{~min}$ and then ramped to $200{ }^{\circ} \mathrm{C}$ at $25^{\circ} \mathrm{C} / \mathrm{min}$, then from 200 to $260{ }^{\circ} \mathrm{C}$ at $3{ }^{\circ} \mathrm{C} /$ min and finally from 260 to $320^{\circ} \mathrm{C}$ at $20^{\circ} \mathrm{C} /$ min where it was held for $2 \mathrm{~min}$. The mass spectrometer was operated in Electron Ionisation mode at $70 \mathrm{eV}$, scanning from 40 to $500 \mathrm{amu}$ at $1.5 \mathrm{scans} \mathrm{s}^{-1}$. Hydrocarbons were identified using a library search (NIST08), the diagnostic fragmented ions and the Kovats indices. Individual chromatograms were exported to text files as peak lists containing retention times and peak areas. The identified hydrocarbons were manually aligned based on their retention times and mass spectra.

\section{Statistical analysis}

Chemometric analysis was carried out with Mass Mountaineer software as described in a previous publication [22]. For analysis, the largest peak area in each sample was assigned as $100 \%$, and individual peak areas were normalised to the sum of all peak areas for the selected compounds in each sample. Fifty-three statistically significant compounds were selected by calculating analysis of variance (ANOVA) for each compound between the two classes that showed the greatest difference in means. Peaks with a $p$ value greater than 0.05 were omitted from the statistical analysis (Table 2).

\section{Results}

\section{CHC profiles}

The empty puparia of the seven blow flies and one flesh fly species yielded chemical profiles of 61 peaks with percentage areas exceeding $0.5 \%$ of the total. The chemical profiles consisted of $n$-alkanes (21\%), alkenes (13\%), methyl branched hydrocarbons (64\%) and unknowns (1\%) with the chain length ranging from $\mathrm{C} 18: \mathrm{H}$ to $\mathrm{C} 33: \mathrm{H}$ (Table 2). For this study, the double bond positions were not determined for the alkenes and alkadienes. In general, the odd numbered $n$-alkanes yielded significantly larger peak areas, with heptacosane $(\mathrm{C} 27: \mathrm{H}$, peak 22) dominating the profiles in most species, followed by nonacosane (C29:H, peak 41). The most dominant methyl branched hydrocarbon was 3-methylheptacosane.

Calliphora vicina from Spain had the largest number of alkenes within its profile (10\%). A number of these alkenes were observed in the Spanish specimens only (i.e. not observed in C. vicina from Norway, Germany or England). Moreover, C. vicina from Spain revealed several other geographically specific compounds, such as peaks 3, 5, 6, 8, 9, 12, 13, 17, 19, 20 and 21 (Table 1). 


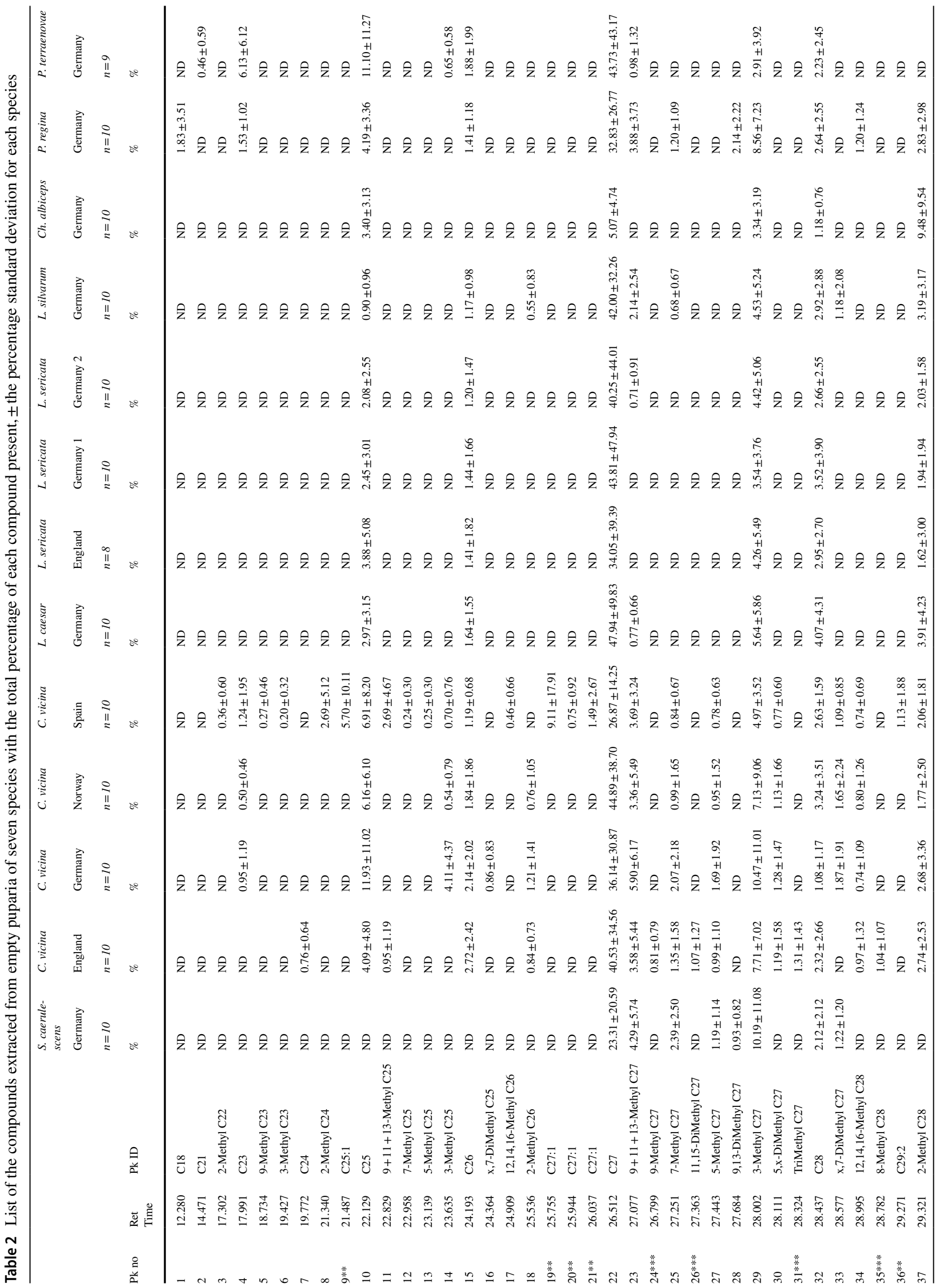




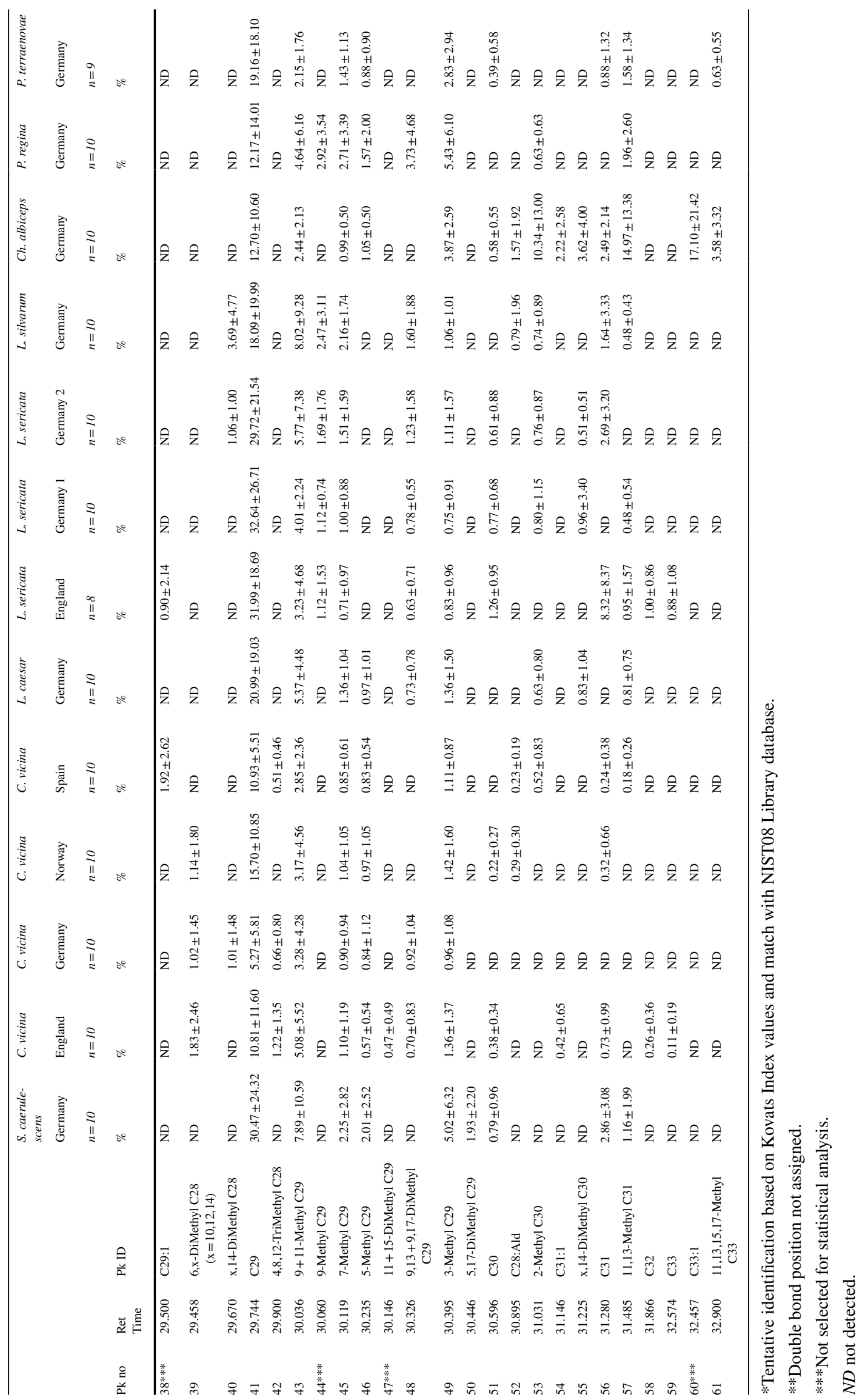


Calliphora vicina from England revealed two geographically specific compounds which were tetracosane $(24: \mathrm{H}$, peak 7) and 11+15-dimethyl nonacosane (peak 47). The profile of $C$. vicina Germany was the only one to contain $\mathrm{x}, 7$-dimethyl pentacosane (peak 16). Distinctions between C. vicina by geographical origin can be seen in the principal component analysis plot shown in Figure S2.

Phormia regina had a species-specific compound which was octadecane $(\mathrm{C} 18: \mathrm{H}$, peak 1)) and P. terraenovae has a compound unique to its chemical profile of heneicosane $\mathrm{C} 21: \mathrm{H}$ (peak 2). Tritriacontene (C33:1) was only observed in Ch. albiceps and the two species from England (C. vicina and $L$. sericata) both shared two compounds in common, dotriacontane $(\mathrm{C} 32: \mathrm{H}$, peak 58) $)$ and tritriacontane $(\mathrm{C} 33: \mathrm{H}$, peak 59), implying that they were geographically specific but not species specific.

In general, the three geographical sets of $L$. sericata (England, Germany 1, Germany 2) were quite similar, sharing a lot of compounds within their chemical profiles. However, noticeable differences were detected. Germany 2 was the only one of the three geographical locations to yield $9+11+13-$ Methyl C27 (peak 23). L. sericata from England was the only geographical region of the three to detect an alkene within its profile (C29:1, Peak 38), while peak 55 (x, 14-DiMethyl C30 was detectable in both Germany 1 and 2 and not in the England samples, implying that they were geographically specific but not species specific. The higher chain length n-alkanes (C31, C32 and C33) were all detectable in L. sericata England; however, of the three alkanes, only $\mathrm{C} 31$ was detectable in Germany 2, and none were detectable in Germany 1, making C32 and C33 geographically specific. Distinctions between $L$. sericata by geographical origin can be seen in the principal component analysis plot shown in Figure S3.

\section{Chemical identification}

All chromatograms are displayed as a heat map in Fig. 1. The heat map is a visual aid, enabling multiple chromatographs to be efficiently stacked and grouped by species and geographic origin for comparison in a small vertical space, in which darker spots represent larger peak areas. For example, the most abundant compound, with a retention time of around $26.5 \mathrm{~min}$ on the heat map, is $\mathrm{C} 27$ (Table 2, peak number 22 ). The pattern valid for the corresponding species or its geographical origin is located under the respective coloured line with results from up to 10 individual replicate samples. The compounds used for classifying are presented in Table 2.

As an unsupervised method, the principal component analysis (PCA) was carried out to determine whether there are sufficient chemical differences between classes to justify further analysis. PCA calculated using the correlation matrix (Figure S4) shows clustering for members of each class, with each class assigned a different colour. However, the separation between class members in this figure is difficult to clearly visualise. The supervised learning method linear discriminant analysis (LDA) shows a visually clearer separation between classes (Fig. 2).

Although LDA already showed visual separation between classes, support vector machine (SVM) classification was chosen as the most efficient classifier. SVM is a supervised learning method that does not produce a graphical display, but which is a highly effective classifier. Leave-one-out cross validation (LOOCV) with SVM gave 100\% classification accuracy. Additional validation was carried out by omitting 30 percent of the samples from the training set to be treated as "unknowns." SVM classification correctly identified the genus, species and geographic origin of $100 \%$ of the "unknowns" (Table S1).

\section{Discussion}

Chemotaxonomy within the field of entomology has been around for many years, and it is widely accepted that CHC analysis provides an excellent means of species identification across a broad range of insect orders like Hymenoptera [15, 23-32], Isoptera [14, 33], Blattodea [31, 34, 35] and Coleoptera [28-30]. CHC analysis has also been used for Diptera [7, 22, 31, 36-39], providing a complementary technique when the taxonomical identification is ambiguous or even not feasible, which could be due to the damaged physical condition or DNA degradation, or quite simply because the morphology between particular species is too similar to identify them [22, 40].

Necrophagous flies are the most important indicators in forensic entomology as they provide a wealth of information within an investigation, from evidence of neglect of living persons or persons who have died because of it, over toxicological histories of deceased persons to the determination of a $\mathrm{PMI}_{\min }$ [41]. Moreover, possible geographical variability of single species could provide information whether or not the victim had been relocated from the site at which death occurred [42].

A number of papers have begun to explore the potential of using $\mathrm{CHC}$ for species identification or population assignment and ageing various life stages of forensically important Calliphoridae [22, 36, 43-47].

Byrne et al. [48] studied the chemical changes between different geographical populations of the black blow fly, Phormia regina. Populations from three locations were examined and using GC-MS analysis to analyse and identify the $\mathrm{CHCs}$; they were able to successfully distinguish between the different locations. Brown et al. [49] examined the CHC compositions of male and female Chrysomya bezziana from 15 different locations covering Africa, the Middle 
Fig. 1 Heat map of all 61 compounds from the 8 species (thirteen data sets), showing species-dependent and geographical-dependent differences in the chromatograms. The $x$-axis represents the retention time, and the chromatographs are grouped along the $y$-axis by species

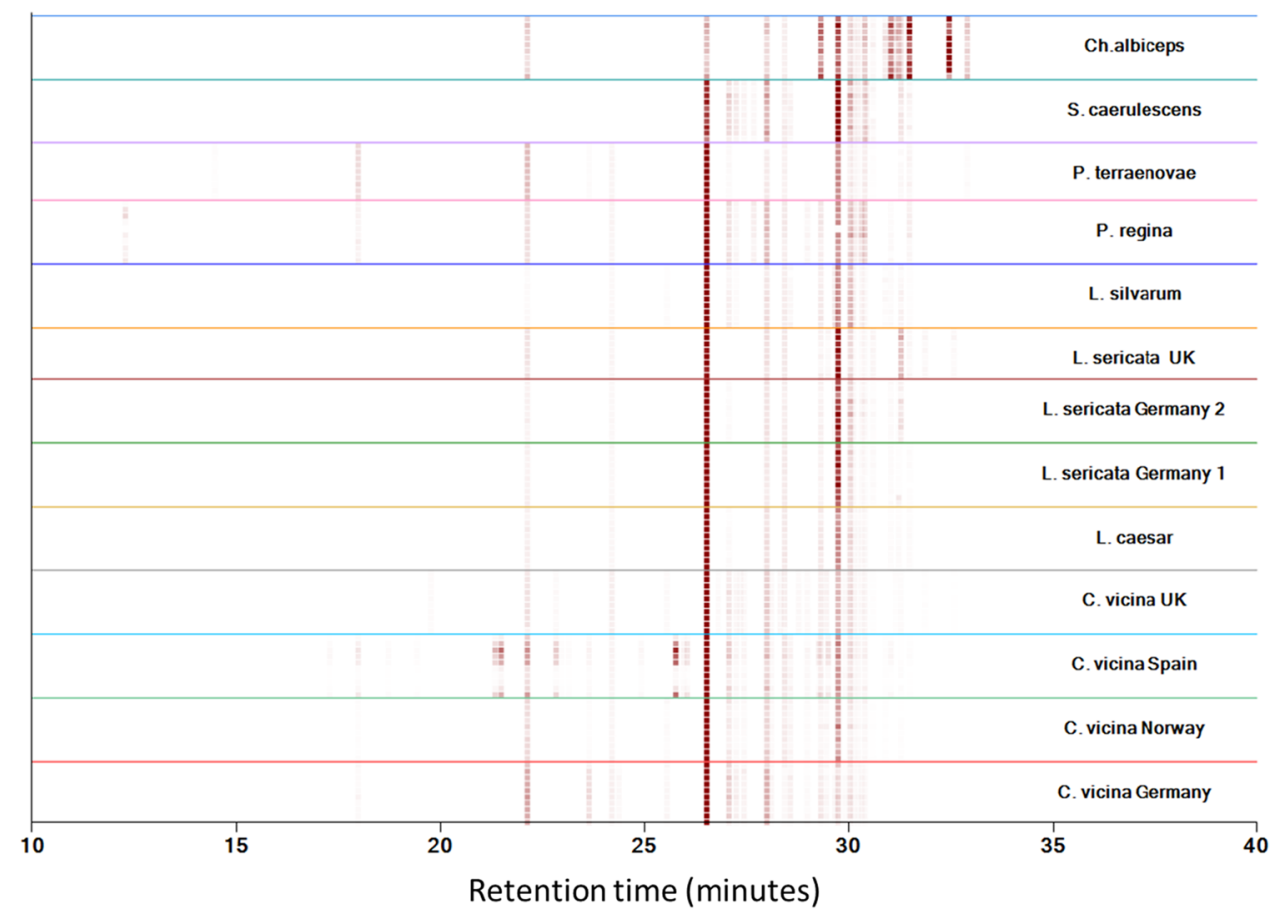

East, India, Southeast Asia and Papua New Guinea. Due to the fact this species is known to be a parasite of warmblooded animals, tracking their geographical location to determine the origin of flies is very important. Their results showed qualitative similarities but quantitative differences, allowing for the differentiation between the geographical locations. Ye et al. [7] examined the chemical composition from six necrophagous flies to determine their taxonomic differentiation. They were able to chemically distinguish all species under controlled laboratory conditions. Moore et al. [22] were the first to carry out an extensive study on the identification of 11 species of Sarcophagidae (males and females) from dry pinned museum samples. This family of Diptera can be notoriously challenging to taxonomically identify, and the results presented in this paper are especially relevant for the flesh fly females, which are known to be more difficult to identify than males using morphological criteria.
Fig. 2 Linear discriminant analysis (LDA) showing clearer visual separation between classes

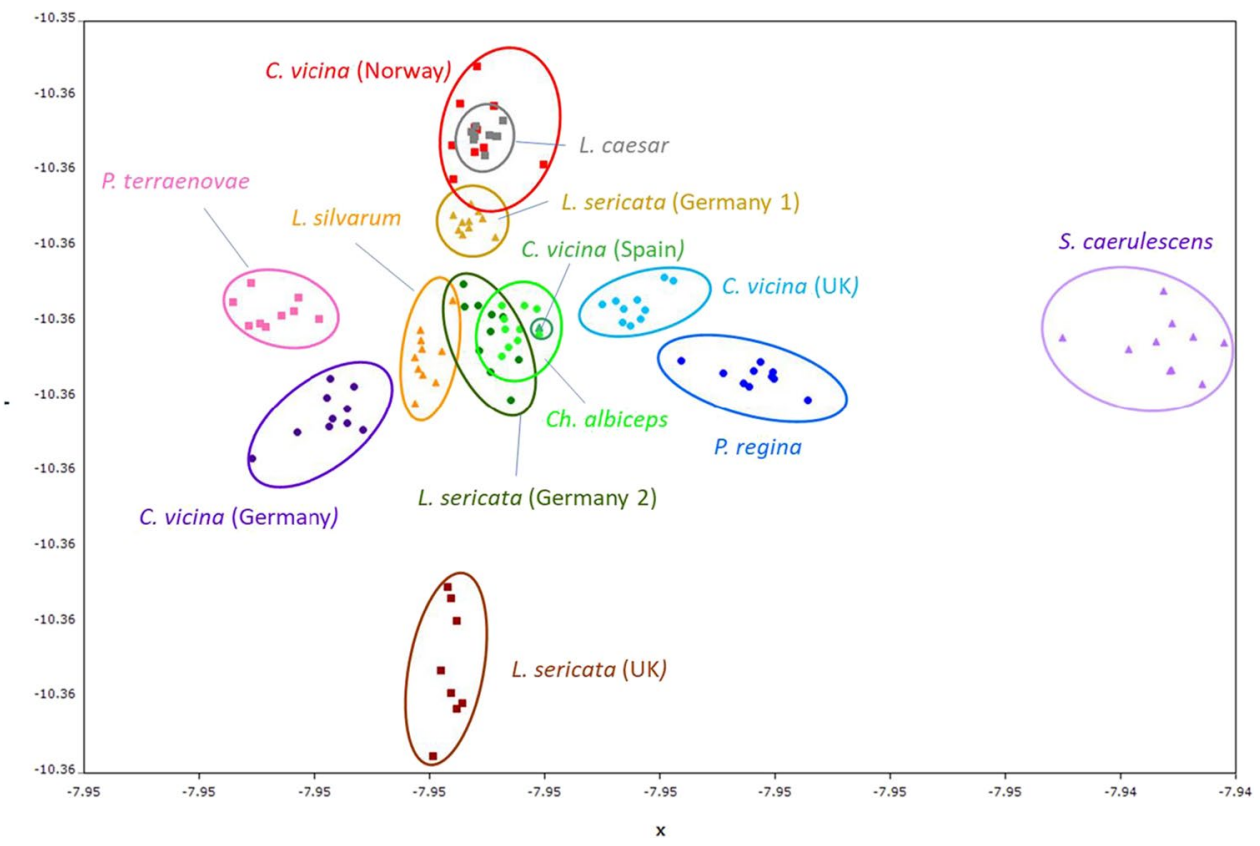


Just a few studies are addressing empty puparia for identification so far and looked also at the difference of geographical location and how the local climate or habitat might alter the chemical profiles of the necrophagous flies and/or their puparia.

Braga et al. [38] successfully examined the cuticular hydrocarbon profiles of four species of Sarcophagidae of forensic importance in South America-Peckia chrysostoma (Wiedemann), P. intermutans (Walker), P. lambens (Wiedemann) and Sarcophaga ruficornis (Fabricius) - using empty puparia. The specimens were reared in the laboratory in a controlled environment and analysed by using GC-MS and. By applying Bray-Curtis distances to the data sets, Braga et al. could successfully discriminate between all four species. Musah et al. [50] examined species classification from chemical fingerprint signatures using direct analysis in real time (DART) mass spectrometry. This method was applied to a variety of species which included endangered woods, biodiesel feedstocks, psychoactive plant products and Eucalyptus. It was also successfully applied to empty puparia of Chrysomya rufifacies, Lucilia sericata, L. cuprina and Cochliomyia macellaria allowing for these species to be chemically distinguishable from their $\mathrm{CHC}$ profiles.

As with adult and immature stages, morphology and DNA are options for identifying puparia of forensically important Diptera. But due to the facts that in puparia the number of helpful diagnostic features at species level is significantly lower than in adults, that they are more difficult to recognise than in larvae due to their dark colouration and that, depending on the crime scene and time of storage, they are often covered with dust and dirt, which obscure the diagnostic features, a correct identification of the specimens is difficult or even impossible and requires sufficient experience [51]. DNA might be a useful alternative, since genotyping can be quick and simple compared to morphological analysis of specimens and the time-consuming rearing procedure to obtain adult specimens for identification. The costs of DNA analysis for species identification are negligible in a forensic laboratory, as are possible time aspects. But Mazzanti et al. [52] highlighted some potential pitfalls in DNA based puparia identification like DNA degradation, unsuccessful amplification and contamination. DNA is hard to get from such specimens due to its small amount and the many disturbing chemical components in the puparia. In fact, serious publications on this topic hardly exist. However, recently Pradelli et al. [51] successfully extracted and identified DNA of the blow fly $L$. sericata from dirty puparia cleaned by different chemical methods. But such results need not necessarily be the rule due to the low amount of tissue in a single puparium suitable to extract nucleic acids, and it is therefore important to use complementary and supportive methods.

We showed in the present study that cuticular hydrocarbon analysis is such a method, which can also provide further information. For future studies, it is important to include more taxa (e.g. the important family Muscidae [53]) and to better map intraspecific variability and understand its causes. This would not only validate a basic framework of important $\mathrm{CHCs}$, but perhaps even establish these chemical elements as markers for e.g. stress during the larval growth and metamorphosis. As CHCs are an important communication tool, their presence and amount could indicate e.g. an interaction with competitive species on the diet, and a varying composition and concentration could be an indication of drought stress during the pupal phase. Before reaching this point, however, further studies are necessary to determine the function of individual, potential marker CHCs.

Supplementary Information The online version contains supplementary material available at https://doi.org/10.1007/s00414-022-02786-1.

Acknowledgements The authors would like to thank Anders Aak, Norwegian Institute of Public Health/Norway, and Daniel Martin-Vega, University of Alcalá, Spain, for providing specimens from Norway and Spain

\section{Declarations}

Human and animal rights and informed consent The research within this manuscript does not involve human and/or animals.

Conflict of interest The authors declare no competing interests.

Open Access This article is licensed under a Creative Commons Attribution 4.0 International License, which permits use, sharing, adaptation, distribution and reproduction in any medium or format, as long as you give appropriate credit to the original author(s) and the source, provide a link to the Creative Commons licence, and indicate if changes were made. The images or other third party material in this article are included in the article's Creative Commons licence, unless indicated otherwise in a credit line to the material. If material is not included in the article's Creative Commons licence and your intended use is not permitted by statutory regulation or exceeds the permitted use, you will need to obtain permission directly from the copyright holder. To view a copy of this licence, visit http://creativecommons.org/licenses/by/4.0/.

\section{References}

1. Greenberg B (1991) Flies as forensic indicators. J Med Entomol 28:565-577

2. Donovan SE, Hall MJR, Turner BD, Moncrieff CB (2006) Larval growth rates of the blowfly, Calliphora vicina, over a range of temperatures. Med Vet Entomol 20:106-114. https://doi.org/10. 1111/j.1365-2915.2006.00600.x

3. Wang J, Li Z, Chen Y et al (2008) The succession and development of insects on pig carcasses and their significances in estimating PMI in south China. Forensic Sci Int 179:11-18. https://doi. org/10.1016/j.forsciint.2008.04.014

4. Ames C, Turner B, Daniel B (2006) Estimating the post-mortem interval (I): The use of genetic markers to aid in identification of 
Dipteran species and subpopulations. Int Congr Ser 1288:795797. https://doi.org/10.1016/j.ics.2005.09.088

5. Adams ZJO, Hall MJR (2003) Methods used for the killing and preservation of blowfly larvae, and their effect on post-mortem larval length. Forensic Sci Int 138:50-61. https://doi.org/10. 1016/j.forsciint.2003.08.010

6. Zhu GH, Xu XH, Yu XJ et al (2007) Puparial case hydrocarbons of Chrysomya megacephala as an indicator of the postmortem interval. Forensic Sci Int 169:1-5. https://doi.org/10.1016/j. forsciint.2006.06.078

7. Ye G, Li K, Zhu J et al (2007) Cuticular hydrocarbon composition in pupal exuviae for taxonomic differentiation of six necrophagous flies. J Med Entomol 44:450-456. https://doi.org/ 10.1093/jmedent/44.3.450

8. Harvey ML, Dadour IR, Gaudieri S (2003) Mitochondrial DNA cytochrome oxidase I gene: potential for distinction between immature stages of some forensically important fly species (Diptera) in western Australia. Forensic Sci Int 131:134-139. https://doi.org/10.1016/S0379-0738(02)00431-0

9. Wallman JF, Donnellan SC (2001) The utility of mitochondrial DNA sequences for the identification of forensically important blowflies (Diptera: Calliphoridae) in southeastern Australia. Forensic Sci Int 120:60-67. https://doi.org/10.1016/S03790738(01)00426-1

10. Cainé LM, Corte Real F, Saloña-Bordas MI et al (2009) DNA typing of Diptera collected from human corpses in Portugal. Forensic Sci Int 184:2008-2010. https://doi.org/10.1016/j.forsc iint.2008.10.016

11. Ratcliffe ST, Webb DW, Weinzievr RA, Robertson HM (2003) PCR-RFLP Identification of Diptera (Calliphoridae, Muscidae and Sarcophagidae) a generally applicable method. J Forensic Sci 48:2002136. https://doi.org/10.1520/jfs2002136

12. Mazzanti M, Alessandrini F, Tagliabracci A et al (2010) DNA degradation and genetic analysis of empty puparia: genetic identification limits in forensic entomology. Forensic Sci Int 195:99-102. https://doi.org/10.1016/j.forsciint.2009.11.022

13. Gibbs AG, Crockettj EL (1998) The biology of lipids: integrative and comparative perspectives. Am Zool 38:265-267. https://doi.org/10.1093/icb/38.2.265

14. Haverty MI, Woodrow RJ, Nelson LJ, Grace JK (2000) Cuticular hydrocarbons of termites of the Hawaiian Islands. J Chem Ecol 26:1167-1191. https://doi.org/10.1023/A:1005479826651

15. Fletcher MT, Allsopp PG, McGrath MJ et al (2008) Diverse cuticular hydrocarbons from Australian canebeetles (Coleoptera: Scarabaeidae). Aust J Entomol 47:153-159. https://doi. org/10.1111/j.1440-6055.2008.00643.x

16. Gibbs A, Pomonist JG (1995) Physical properties of insect cuticular hydrocarbons : The effects of chain length, methyl-branching and unsaturation. Comp Biochem Physiol 112B:243-249

17. Drijfhout FP (2010) Cuticular hydrocarbons: a new tool in forensic entomology. In: Amendt J, Campobasso CP, Goff ML, Grassberger M (eds) Current Concepts in Forensic Entomology. Springer, pp 179-203

18. Martin SJ, Helanterä H, Drijfhout FP (2008) Colony-specific hydrocarbons identify nest mates in two species of Formica ant. J Chem Ecol 34:1072-1080. https://doi.org/10.1007/ s10886-008-9482-7

19. Everaerts C, Farine JP, Brossut R (1997) Changes of species specific cuticular hydrocarbon profiles in the cockroaches $\mathrm{Nau}$ phoeta cinerea and Leucophaea maderae reared in heterospecific groups. Behav Ecol Sociobiol 145-150

20. Szpila K (2012) Key for identification of European and Mediterranean blowflies (Diptera, Calliphoridae) of medical and veterinary importance-adult flies. In: Forensic entomology, an intorduction. Willey-Blackwell, pp 77-81
21. Szpila K, Richet R, Pape T (2015) Third instar larvae of flesh flies (Diptera: Sarcophagidae) of forensic importance-critical review of characters and key for European species. Parasitol Res 114:2279-2289. https://doi.org/10.1007/s00436-015-4421-3

22. Moore HE, Hall MJR, Drijfhout FP et al (2021) Cuticular hydrocarbons for identifying Sarcophagidae (Diptera). Sci Rep 11:7732. https://doi.org/10.1038/s41598-021-87221-y

23. Tissot M, Nelson DR, Gordon DM (2001) Qualitative and quantitative differences in cuticular hydrocarbons between laboratory and field colonies of Pogonomyrmex barbatus. Comp Biochem Physiol - B Biochem Mol Biol 130:349-358. https://doi.org/10. 1016/S1096-4959(01)00436-5

24. Akino T, Yamamura K, Wakamura S, Yamaoka R (2004) Direct behavioral evidence for hydrocarbons as nestmate recognition cues in Formica japonica (Hymenoptera: Formicidae). Appl Entomol Zool 39:381-387. https://doi.org/10.1303/aez.2004.381

25. Martin SJ, Vitikainen E, Helanterä H, Drijfhout FP (2008) Chemical basis of nest-mate discrimination in the ant Formica exsecta. Proc R Soc B Biol Sci 275:1271-1278. https://doi.org/10.1098/ rspb.2007.1708

26. van Wilgenburg E, Symonds MRE, Elgar MA (2011) Evolution of cuticular hydrocarbon diversity in ants. J Evol Biol 24:1188-1198

27. Morrison WR, Witte V (2011) Strong differences in chemical recognition cues between two closely related species of ants from the genus Lasius (Hymenoptera: Formicidae). J Evol Biol 24:2389-2397. https://doi.org/10.1111/j.1420-9101.2011.02364.x

28. Page M, Nelson L, Haverty M, Blomquist G (1990) Cuticular hydrocarbons of eight species of North Americancone beetles, Conophthorus ponderosae. J Chem Ecol 16:1173-1198

29. Page M, Nelson LJ, Blomquist GJ, Seybold SJ (1997) Cuticular hydrocarbons as chemotaxonomic characters of pine engraver beetles (Ips spp.) in the grandicollis subgeneric group. J Chem Ecol 23:1053-1099. https://doi.org/10.1023/B:JOEC.0000006388. 92425.ec

30. Niogret J, Felix AE, Nicot A, Lumaret JP (2019) Chemosystematics using cuticular compounds: a powerful tool to separate species in mediterranean dung beetles (Coleoptera: Geotrupidae). J Insect Sci 19(2):18. https://doi.org/10.1093/jisesa/iez026

31. Carlson DA (1988) Hydrocarbons for identification and phenetic comparisons: cockroaches, honey bees and tsetse flies. Florida Entomol 71:333. https://doi.org/10.2307/3495441

32. Lavine BK, Vora MN (2005) Identification of Africanized honeybees. J Chromatogr A 1096:69-75. https://doi.org/10.1016/j. chroma.2005.06.049

33. Haverty MI, Collins MS, Nelson LJ, Thorne BL (1997) Cuticular hydrocarbons of termites of the British Virgin Islands. J Chem Ecol 23:927-964

34. Everaerts C, Farine JP, Brossut R (1997) Changes of species specific cuticular hydrocarbon profiles in the cockroaches Nauphoeta cinerea and Leucophaea maderae reared in heterospecific groups. Entomol Exp Appl 85:145-150. https://doi.org/10.1046/j.15707458.1997.00244.x

35. Brown WV, Rose HA, Lacey MJ, Wright K (2000) The cuticular hydrocarbons of the giant soil-burrowing cockroach Macropanesthia rhinoceros Saussure (Blattodea: Blaberidae: Geoscapheinae): analysis with respect to age, sex and location. Comp Biochem Physiol - B Biochem Mol Biol 127:261-277. https://doi.org/ 10.1016/S0305-0491(00)00212-1

36. Musah RA, Espinoza EO, Cody RB et al (2015) A high throughput ambient mass spectrometric approach to species identification and classification from chemical fingerprint signatures. Sci Rep 5:11520. https://doi.org/10.1038/srep11520

37. Moore HE, Adam CD, Drijfhout FP (2014) Identifying 1st instar larvae for three forensically important blowfly species using "fingerprint" cuticular hydrocarbon analysis. Forensic Sci Int 240:48-53. https://doi.org/10.1016/j.forsciint.2014.04.002 
38. Braga MV, Pinto ZT, de Carvalho Queiroz MM et al (2013) Cuticular hydrocarbons as a tool for the identification of insect species: puparial cases from Sarcophagidae. Acta Trop 128:479-485. https://doi.org/10.1016/j.actatropica.2013.07.014

39. Urech R, Brown GW, Moore CJ, Green PE (2005) Cuticular hydrocarbons of buffalo fly, haematobia exigua, and chemotaxonomic differentiation from Horn Fly. H irritans J Chem Ecol 31:2451-2461. https://doi.org/10.1007/s10886-005-7112-1

40. Braga MV, Pinto ZT, de Carvalho Queiroz MM et al (2013) Cuticular hydrocarbons as a tool for the identification of insectspecies: Puparial cases from Sarcophagidae. Acta Tropica 128:479-485

41. Amendt J, Campobasso CP, Gaudry E et al (2007) Best practice in forensic entomology - standards and guidelines. Int J Legal Med 121:90-104. https://doi.org/10.1007/s00414-006-0086-X

42. Charabidze D, Gosselin M, Hedouin V (2017) Use of necrophagous insects as evidence of cadaver relocation: myth or reality? PeerJ 2017:1-32. https://doi.org/10.7717/peerj.3506

43. Pechal JL, Moore H, Drijfhout F, Benbow ME (2014) Hydrocarbon profiles throughout adult Calliphoridae aging: a promising tool for forensic entomology. Forensic Sci Int 245:65-71. https:// doi.org/10.1016/j.forsciint.2014.10.019

44. Roux O, Gers C, Legal L (2008) Ontogenetic study of three Calliphoridae of forensic importance through cuticular hydrocarbon analysis. Med Vet Entomol 22:309-317. https://doi.org/10.1111/j. 1365-2915.2008.00752.x

45. Zhu GH, Yu XJ, Xie LX et al (2013) Time of death revealed by hydrocarbons of empty puparia of Chrysomya megacephala (Fabricius) (Diptera: Calliphoridae): a field experiment. PLoS ONE 8(9):e73043. https://doi.org/10.1371/journal.pone.0073043

46. $\mathrm{Xu} \mathrm{H}, \mathrm{Ye} \mathrm{GY,} \mathrm{Xu} \mathrm{Y} \mathrm{et} \mathrm{al} \mathrm{(2014)} \mathrm{Age-dependent} \mathrm{changes} \mathrm{in} \mathrm{cuticu-}$ lar hydrocarbons of larvae in Aldrichina grahami (Aldrich) (Diptera: Calliphoridae). Forensic Sci Int 242:236-241. https://doi. org/10.1016/j.forsciint.2014.07.003
47. Braga MV, Pinto ZT, de Carvalho Queiroz MM, Blomquist GJ (2016) Effect of age on cuticular hydrocarbon profiles in adult Chrysomya putoria (Diptera: Calliphoridae). Forensic Sci Int 259:e37-e47. https://doi.org/10.1016/j.forsciint.2015.11.006

48. Byrne AL, Camann MA, Cyr TL et al (1995) Forensic implications of biochemical differences among geographic populations of the black blow fly, Phormia regina (Meigen). J Forensic Sci 40:13789J. https://doi.org/10.1520/jfs13789j

49. Brown WV, Morton R, Lacey MJ et al (1998) Identification of the geographical source of adults of the old world screw-worm fly, Chrysomya bezziana Villeneuve (Diptera: Calliphoridae), by multivariate analysis of cuticular hydrocarbons. Comp Biochem Physiol - B Biochem Mol Biol 119:391-399. https://doi.org/10. 1016/S0305-0491(97)00365-9

50. Musah RA, Espinoza EO, Cody RB et al (2015) A high throughput ambient mass spectrometric approach to species identification and classification from chemical fingerprint signatures. Sci Rep 5:1-16. https://doi.org/10.1038/srep11520

51. Pradelli J, Tuccia F, Giordani G, Vanin S (2021) Puparia cleaning techniques for forensic and archaeo-funerary studies. Insects 12:1-9. https://doi.org/10.3390/insects 12020104

52. Mazzanti M, Alessandrini F, Tagliabracci A et al (2010) DNA degradation and genetic analysis of empty puparia: Genetic identification limits in forensic entomology. Forensic Science International 195:99-102. https://doi.org/10.1016/j.forsciint.2009.11.022

53. Grzywacz A, Hall MJR, Pape T, Szpila K (2017) Muscidae (Diptera) of forensic importance-an identification key to third instar larvae of the western Palaearctic region and a catalogue of the muscid carrion community. Int J Legal Med 131:855-866. https:// doi.org/10.1007/s00414-016-1495-0

Publisher's note Springer Nature remains neutral with regard to jurisdictional claims in published maps and institutional affiliations. 